\title{
KELIMPAHAN DAN KERAGAMAN BURUNG DI RESORT PEMERIHAN TAMAN NASIONAL BUKIT BARISAN SELATAN
}

\author{
Abundance and Diversity of Birds in Resort Pemerihan Taman Nasional Bukit Barisan Selatan \\ Joana Dwi Wulandari ${ }^{1 *}$, Dian Iswandaru, Sugeng Prayitno Harianto ${ }^{1}$, Yulia Rahma \\ Fitriana $^{1}$, Subki $^{2}$ \\ ${ }^{1}$ Jurusan Kehutanan, Fakultas Pertanian, Universitas Lampung \\ ${ }^{2}$ Balai Besar Taman Nasional Bukit Barisan Selatan \\ *Email : joanadwi@gmail.com
}

Diterima : 05/01/2021, Direvisi : 06/08/2021, Disetujui : 09/08/2021

\begin{abstract}
The abundance of bird species in an area represents how conditions are in the area, such as the Pemerihan Resort, in Bukit Barisan Selatan National Park, as habitat for various wild bird species. The aim of research to analyze of abundance, diversity and conservation status of birds at the Pemerihan Resort. Data collection using the Point count method. The study recorded 76 bird species from 31 families with a total number of 1598 individuals. The highest relative abundance was the pacific swallow (Hirundo tahitica) with KR 23.59\%, and the smallest abundance was the long-tailed shrike(Lanius schach), banded kingfisher (Lacedo pulchella), javan leafbird (Chloropsis cochinchinensis), red-bearded bee-eater (Nyctyornis amictus), redbilled malkoha (Phaenicophaeus javanicus), velvet-fronted nuthatch (Sitta frontalis), rufous piculet (Sasia abnormis), oriental dwarf-kingfisher (Ceyx erithacus), and indigo flycatcher (Eumyias indigo) $0.06 \%$. The higher the species abundance level indicates that the more diverse species found. Many bird species found could benefit the management and the community around the Resort Pemerihan to protect these birds habitat. The data could benefit to implement sustainable use of the Resort, such as the development of birdwatching tourism by holding training guides for birdwatching by involving the community.
\end{abstract}

Key Words: Pemerihan Resort, Birds, Abundance.

\begin{abstract}
ABSTRAK
Kelimpahan spesies burung di suatu daerah dapat menunjukkan bagaimana kondisi di daerah tersebut, seperti Resort Pemerihan di Taman Nasional Bukit Barisan Selatan, yang merupakan habitat berbagai spesies burung liar. Tujuan penelitian untuk menganalisis kelimpahan dan keragaman serta status konservasi burung di Resort Pemerihan. Pengumpulan data menggunakan metode Point count. Hasil studi mencatat ada 76 spesies burung dari 31 famili dengan jumlah total 1598 individu. Kelimpahan relatif (KR) tertinggi adalah spesies layanglayang batu (Hirundo tahitica) dengan KR 23,59\% dan kelimpahan terkecil adalah spesies bentet kelabu (Lanius schach), cekakak batu (Lacedo pulchella), cica-daun sayap-biru (Chloropsis cochinchinensis), cirik-cirik kumbang (Nyctyornis amictus), kadalan kembang
\end{abstract}


(Phaenicophaeus javanicus), munguk beledu (Sitta frontalis), tukik tikus (Sasia abnormis), udang api (Ceyx erithacus), dan sikatan ninon (Eumyias indigo) 0,06\%. Semakin tinggi tingkat kelimpahan spesies menunjukan bahwa semakin beragam spesies yang ditemukan. Dengan ketersediaan data mengenai banyaknya jenis burung yang ditemukan, diharapkan data tersebut dapat menjadi dasar penelitian lebih lanjut terkait pelestarian burung di Resort Pemerihan.

Kata Kunci: Resort Pemerihan, Burung, Kelimpahan.

\section{PENDAHULUAN}

Burung merupakan satwa penting dalam menjaga regenerasi hutan dan juga berperan dalam menjaga fungsi dan keseimbangan ekosistem hutan (Tesfahunegry et al., 2016; Kiros et al., 2018; Iswandaru et al., 2020). Satwa ini dapat berperan sebagai pengontrol serangga hama, penyebar biji dan penyerbuk bunga (Oktiana dan Antono 2015; Anugrah et al., 2017; Muchlas et al., 2018). Berdasarkan data keragaman burung global, Indonesia berada pada posisi keempat dari daftar negara burung terkaya di dunia, setelah Brazil, Columbia dan Peru, dan daftar pertama untuk endemis (Iskandar et al., 2019; Iswandaru et al., 2020 ).

Burung memerlukan beberapa syarat untuk keberlangsungan hidupnya, antara lain kondisi habitat yang sesuai dan aman dari segala macam gangguan (Dharmojono, 1996; Kamal et al., 2013; Rohiyan et al., 2014). Habitat yang kondisinya baik dan jauh dari gangguan manusia serta di dalamnya mengandung bermacam-macam sumber pakan, memungkinkan memiliki jenis burung yang banyak (Widodo, 2009; Simanjuntak et al., 2013; Santosa et al., 2016; Adelina et al., 2016). Perusakan habitat alami besar-besaran terjadi karena aktivitas urbanisasi (Hong dan Mohd-Azlan 2018; Ichsan, 2018). Menurut Naithani et al., (2018), urbanisasi maupun industrialisasi merupakan sumber gangguan bagi burung. Kegiatan urbanisasi menyebabkan degradasi habitat dan fragmentasi yang mengakibatkan penurunan keanekaragaman hayati secara keseluruhan (Baskaran et al., 2013; Achsan et al., 2019; Wahyuni et al., 2020). Keberadaan burung dapat menjadi indikator sebuah lingkungan mendukung kehidupan suatu organisme atau tidak karena burung mempunyai hubungan timbal balik dan saling tergantung dengan lingkungannya (Paramita et al., 2015; Wulandari et al., 2019). Salah satu potensi burung yang melimpah terdapat di Taman Nasional Bukit Barisan Selatan (TNBBS). Berdasarkan studi yang dilakukan Tropical Forest Conservation ActionSumatera (TFCAS) tahun 2019 di TNBBS ditemukan burung sebanyak 450 jenis. TNBBS merupakan salah satu kawasan pelestarian alam yang memiliki banyak potensi, baik fauna maupun flora yang tergolong langka (Meizannur dan Wulandari, 2015), salah satunya di Resort Pemerihan. Namun, informasi dan data mengenai keanekaragaman burung di Resort Pemerihan masih terbatas karena belum pernah dilakukan penelitian sebelumnya.

Resort Pemerihan secara geografis terletak pada 4029'-5057' LS, dan 103024'-104044' BT dan merupakan wilayah Seksi Pengembangan Taman Nasional (SPTN) Wilayah II Bengkunat Kabupaten Pesisir Barat dengan luasan 17.902 ha (Balai Besar Taman Nasional Bukit Barisan Selatan/BBTNBBS, 2014). Wilayah Resort Pemerihan memiliki beberapa macam tipe habitat vegetasi dan tutupan lahan yang berbeda yaitu vegetasi hutan alam, vegetasi sungai, dan jalan utama sehingga potensial menjadi area singgah dan habitat burung. Dengan demikian, diperlukan penelitian mengenai kelimpahan jenis burung untuk mendukung pengelolaan sumberdaya alam di Resort Pemerihan TNBBS. Tujuan penelitian adalah menganalisis kelimpahan dan keragaman serta status konservasi jenis burung yang terdapat di Resort Pemerihan TNBBS. 


\section{METODE}

Penelitian ini dilaksanakan di Resort Pemerihan, Taman Nasional Bukit Barisan Selatan (Gambar 1), pada bulan Agustus 2020.Resort Pemerihan secara geografis terletak antara $104^{\circ}$

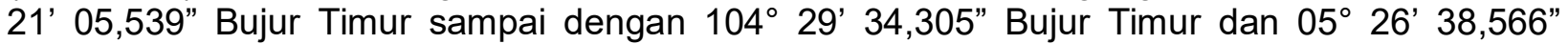

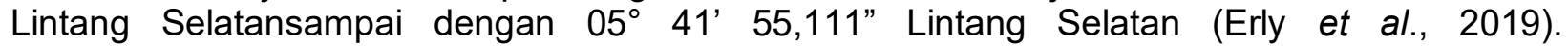
MenurutSchmidt dan Ferguson, tipe hujan di Resort Pemerihan adalah tipe A dengan curah hujan sebesar 2.500 - 3.000 mm per tahun (Balai Besar Taman Nasional Bukit Barisan Selatan, 2017a; Erly et al., 2019). Temperaturberkisar $31^{\circ} \mathrm{C}$. Ketinggian resort $20-500 \mathrm{~m}$ dpl, dengan kelerengan didominasi datar $(0 \%-8 \%)$ yaitusebesar $43,35 \%$ dari luas wilayah (Balai Besar Taman Nasional Bukit Barisan Selatan 2017b). Jenis tanah di Resort Pemerihan didominasi oleh tanah Aluvial dan PodsolikMerah Kuning (Wardani et al., 2016; Erly et al., 2019). Peralatan yang digunakan dalam penelitian ini adalah: tally sheet, binocular, GPS, perekam suara, kamera, kompas, dan buku panduan lapangan MacKinnon (2010) identifikasi jenis burung seri "Panduan Lapangan Identifikasi Jenis Burung di Sumatera, Jawa, Bali dan Kalimantan".Bahan yang digunakan dalam penelitian ini adalah jenis burung yang terdapat di dalam lokasi penelitian.

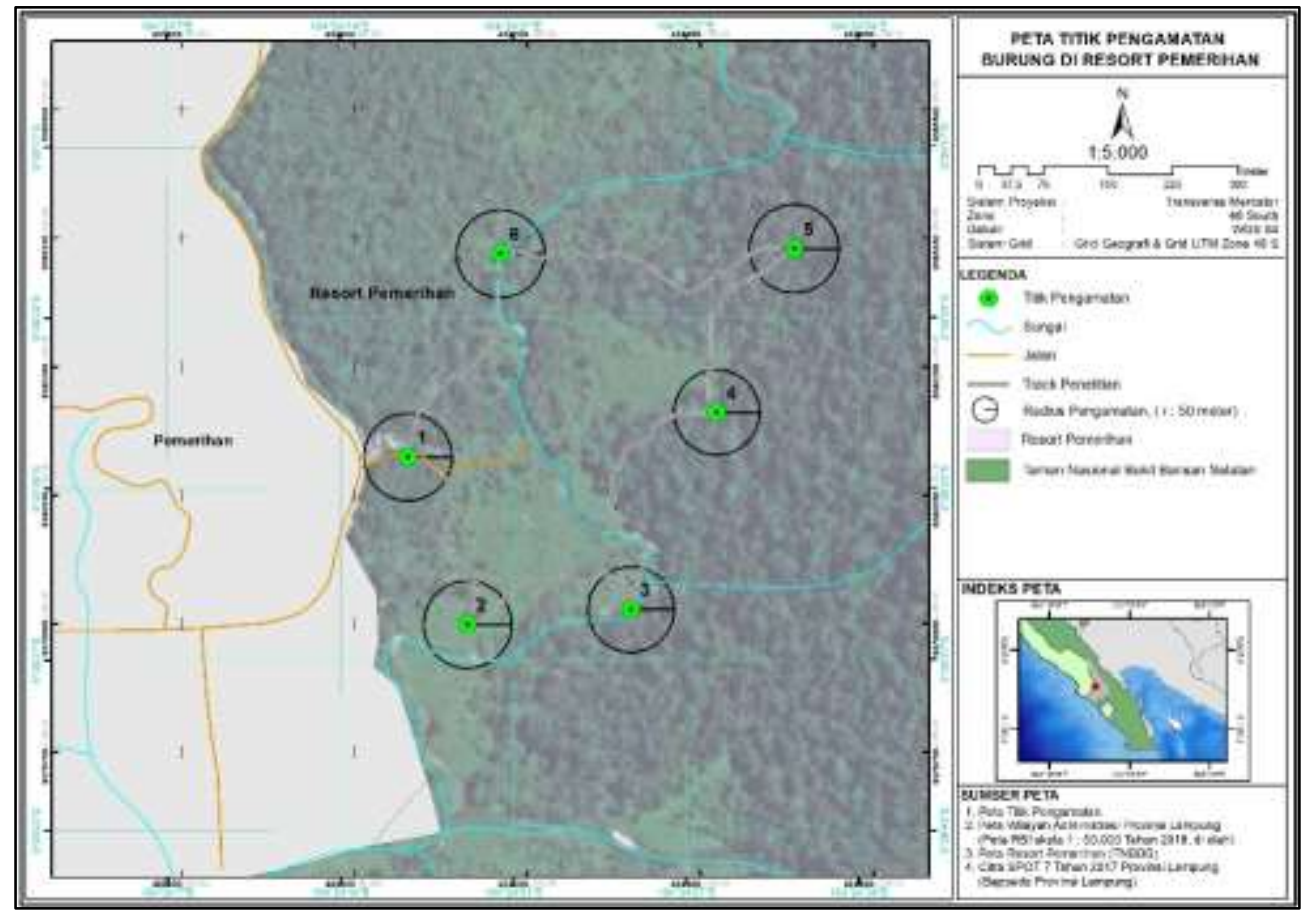

Gambar 1. Peta lokasi pengamatan

Figure 1. Maps of location

Pengumpulan data dilakukan dengan merode point count (Gambar 2). Wilayah yang luas dan terbuka dibuat titik hitung secara purposive berdasarkan pembagian sampel area (wilayah) (Karim et al., 2016).Pengamatan dilakukan dengan diam pada titik tertentu selama 20 menit, kemudian berjalan ketitik berikutnya. yang mewakili tipe habitat. Jarak antar titik hitung 200 meter dengan radius pengamatan sejauh 50 meter. Pengambilan data dilakukan setiap pagi 
hari pukul 06.30-10.00 WIB dan sore hari pukul 15.00-18.00 WIB, yaitu waktu pada saat burung paling aktif pada pagi dan sore hari (MacKinnon et al. 2010; Iswandaru et al. 2020), sehingga mendapatkan presisi yang tepat (Bibby et al., 2000; Ghifari et al., 2016). Pengulangan pada penelitian ini dilakukan sebanyak 6 kali karena terdapat 6 titik pengamatan pada penelitian ini. Pengulangan dilakukan untuk menghindari terjadinya bias data (Sabaruddin et al., 2017), seperti pada penelitian Adelina et al. (2016), yang pada penelitian tersebut terdapat 3 (tiga) titik pengamatan, sehingga dilakukan 3 kali pengulangan. Pengulangan penting dilakukan dengan tujuan memperjelas suau penelitian, memperluas daya cakup kesimpulan penelitian, dan memperbaiki beragam kesalahan dalam penelitian. Setiap perjumpaan burung secara langsung termasuk yang sedang terbang akan dicatat setiap jenisnya (Jhenkar, 2016; Iswandaru et al., 2018).

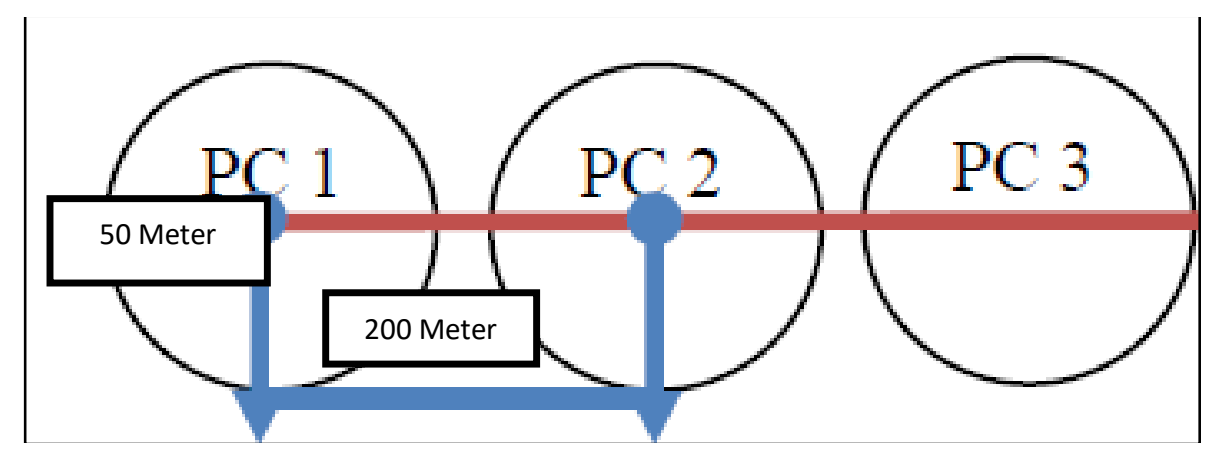

Gambar 2. Point countpada pengamatan burung

Figure 2. Pointcount for bird data collection

Identifikasi jenis burung merujuk pada MacKinnon (2010) dan tata nama burung dalam bahasa Indonesia merujuk pada Sukmantoroet al., (2007). Jenis burung yang teridentifikasi akan dikelompokkan berdasarkan status konservasi berdasarkan International Union for Conservation of Nature (IUCN) yang terdiri dari Not Evaluated (NE), Data Deficent (DD), Least Concern (LC), Near Threatened (NT), Vulnerable (VU), Endangered (EN), Critically Endangered (CE), Extinct in the Wild (EW), Extinct (EX). Status perdagangan menurut The Convention on International Trade in Endangered Species of Wild Fauna and Flora (CITES) yang terdiri dari Apendiks I,II dan III, serta Permen LHK No. 106 Tahun 2018 tentang Jenis Tumbuhan dan Satwa Dilindungi yang terdiri dari satwa Dilindungi (D) dan Tidak Dilindungi (TD).

Indeks keanekaragaman dapat dihitung dengan rumus Shannon-Wienner (Magurran, 1988). Dimana pi adalah kelimpahan proporsional setiap spesies $=$ ni $/ \mathrm{N}$.

$$
H^{\prime}=-\sum p i \ln p i
$$

Kelimpahan relatif setiap jenis sangat dipengaruhi oleh banyaknya jumlah individu pada suatu lokasi atau habitat. Kelimpahan relatif dihitung menggunakan rumus sebagai berikut (Sulistyadi, 2010; James, 2017; Iswandaru et al., 2018):

$$
K R=\frac{n}{N} \times 100 \%
$$

Keterangan:

$\mathrm{KR}$ : Kelimpahan Relatif 
$\mathrm{n}:$ Jumlah individu setiap jenis

$\mathrm{N}$ : Total individu diseluruh plot pengamatan

\section{HASIL DAN PEMBAHASAN}

\section{A. Kelimpahan dan Keragaman Burung}

Jenis burung dengan Kelimpahan Relatif (KR) tertinggi di Resort Pemerihan TNBBS (Lampiran 2) adalah Hirundo tahitica 23,59\%, kemudian secara berurutan diikuti oleh Pycnonotus aurigaster 9,14\%, Pycnonotus goiavier 6,63\%, sedangkan jenis dengan kelimpahan terkecil adalah Lanius schach, Lacedo pulchella, Chloropsis cochinchinensis, Nyctyornis amictus, Phaenicophaeus javanicus, Sitta frontalis, Sasia abnormis, Ceyx erithacus, Ducula aenea, Eumyias indigo 0,06\%. Hirundo tahitica merupakan jenis burung yang paling banyak ditemukan di Resort Pemerihan, hal tersebut dikarenakan habitat dari burung layang-layang batu cenderung fleksibel (Fajar, 2020). Burung layang-layang batu tersebut teramati sedang melakukan aktivitas terbang secara berkelompok, hal tersebut dikarenakan ukuran burung laying-layang batu kecil, dan pola hidup berkelompok dilakukan sebagai bentuk pertahanan diri dari burung pemangsa (Ayat, 2011). Aktifitas Hirundo tahitica selalu berkelompok kecil dan beristirahat dengan cara bertengger. Menurut Firmandi (2014) layang-layang batu terbang rendah di atas tanah ataupun sungai dan juga seringkali di jumpai pada area persawahan maupun di sekitar permukiman. Makanan utama dari burung tersebut adalah jenis-jenis serangga, seperti kumbang (Coleoptera), semut (Formicidae), dan rayap (Isoptera) (Gafur et al., 2016; Fajar, 2020). Kelimpahan terendah yaitu Lanius schach, Lacedo pulchella, Chloropsis cochinchinensis, Nyctyornis amictus, Phaenicophaeus javanicus, Sitta frontalis, Sasia abnormis, Ceyx erithacus $0,06 \%$

Burung cica daun sayap biru (Lacedo pulchella) menempati habitat seperti hutan tropis, hutan sekunder, dan hutan-hutan yang lebat pepohonan, makanan yang dapat dimakan seperti serangga dan buah-buahan yang kecil seperti buah kersen (Sabri, 2019), sehingga lokasi penelitian sangat cocok untuk burung cica-daun sayap-biru. Selain habitat yang ideal, rendahnya kelimpahan untuk cica-daun sayap-biru disebabkan karena statusnya Endangered yaitu status konservasi yang diberikan kepada populasi spesies yang sedang menghadapi risiko kepunahan di alam liar yang tinggi pada waktu yang akan datang. Menurut Birdlife (2019) burung cica-daun sayap-biru secara global terus mengalami penurunan yang sangat tajam, diperkirakan populasinya akan merosot hingga $50 \%$ di masa depan karena perburuan secara ilegal (Mukhlisi et al., 2021)

Keanekaragaman jenis burung tiap titik di Resort Pemerihan berbeda-beda, hal tersebut disebabkan oleh bedanya tipe vegetasi, seperti lokasi penelitian terbuka atau tertutup. Dari ke enam titik, keanekaragaman jenis yang paling tinggi adalah Titik ke 5 (Pematang). Gambaran lokasi Titik 5 banyak ditumbuhi pepohonan dengan struktur tajuk yang bervariasi. Burungburung yang ditemukan adalah cucak kuning (Rubigula dispar), rangkong badak (Buceros rhinoceros), cipoh jantung (Aegithina viridissima), merbah cerukcuk (Pycnonotus goiavier), srigunting batu (Dicrurus paradiseus), punai kecil (Treron olax), burung-madu polos (Anthreptes simplex), dan lain-lain. Burung-burung tersebut banyak melakukan aktivitas pada tajuk pohon, khususnya tajuk bagian atas pohon (MacKinnon, et al., 2010). Selain itu, variasi struktur tajuk lebih banyak menyediakan sumber makanan, tempat berteduh dan bersarang (cover), tempat istirahat sementara (shelter) untuk mendukung terbentuknya komunitas burung yang lebih beragam (Iswandaru, et al., 2020). Keberadaan burung juga dipengaruhi oleh kesusaian habitat 
yang didukung oleh kelimpahan makanan dan perlindungan dari predator (Issa, 2019) dan cuaca buruk sehingga cenderung akan dijadikan sebagai habitat utamanya (Rajpar dan Zakaria, 2011).

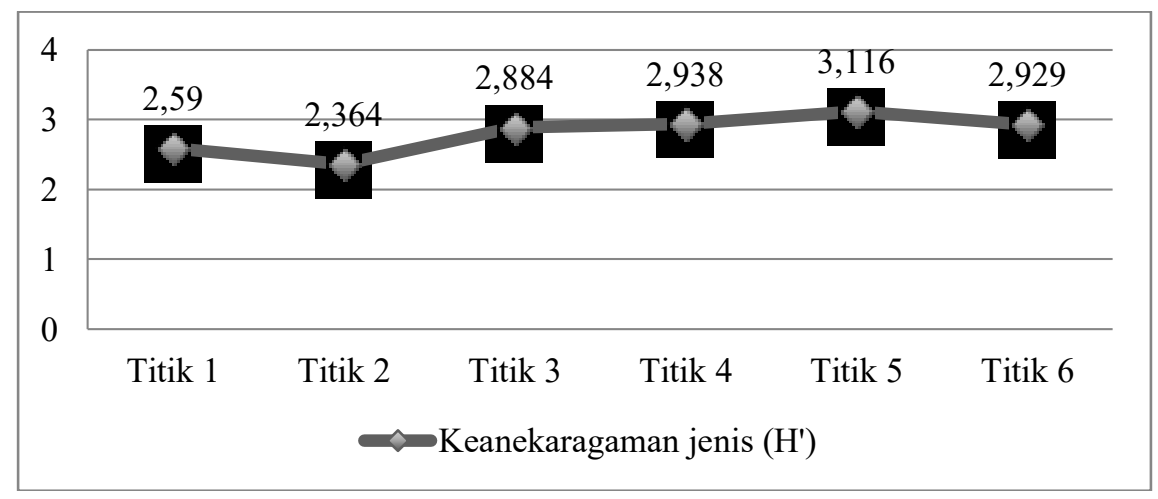

Gambar 4. Keanekaragaman jenis burung di Resort Pemerihan Picture 4. Diversity of Bird Species in Pemerihan Resort

\section{B. Status Konservasi}

Sebanyak 73 jenis burung ditemukan di Resort Pemerihan dengan jumlah individu 1628 yang terdiri dari 32 famili (Lampiran 1). Beberapa jenis burung masuk ke dalam daftar jenis dilindungi berdasarkan Permen LHK No. 106 tahun 2018 (Gambar 3). Sementara itu, jenis burung yang masuk IUCN dengan status konservasi genting/terancam (EN) adalah cica-daun sayap-biru (Chloropsis cochinchinensis), status rentan (VU) adalah rangkong badak (Buceros rhinoceros), status hampir terancam (NT) cica-daun kecil (Chloropsis cyanopogon), cipoh jantung (Aegithina viridissima), kadalan beruang (Phaenicophaeus diardi), kuau raja (Argusianus argus), sempurhujan darat (Eurylaimus ochromalus), takur ampis-sumatera (Caloramphus hayii), takur warna warni (Megalaima mystacophanos), enggang klihingan (Anorrhinus galeritus) dan paok pancawarna-sumatera (Hydrornis irena). Selain itu, 62 jenis lainnya berstatus resiko rendah (LC). Jenis burung yang masuk dalam daftar Appendix CITES adalah alap-alap capung, elangular bido dan rangkong badak dengan kategori All (Appendix II), sehingga dilarang untuk diperdagangkan. 


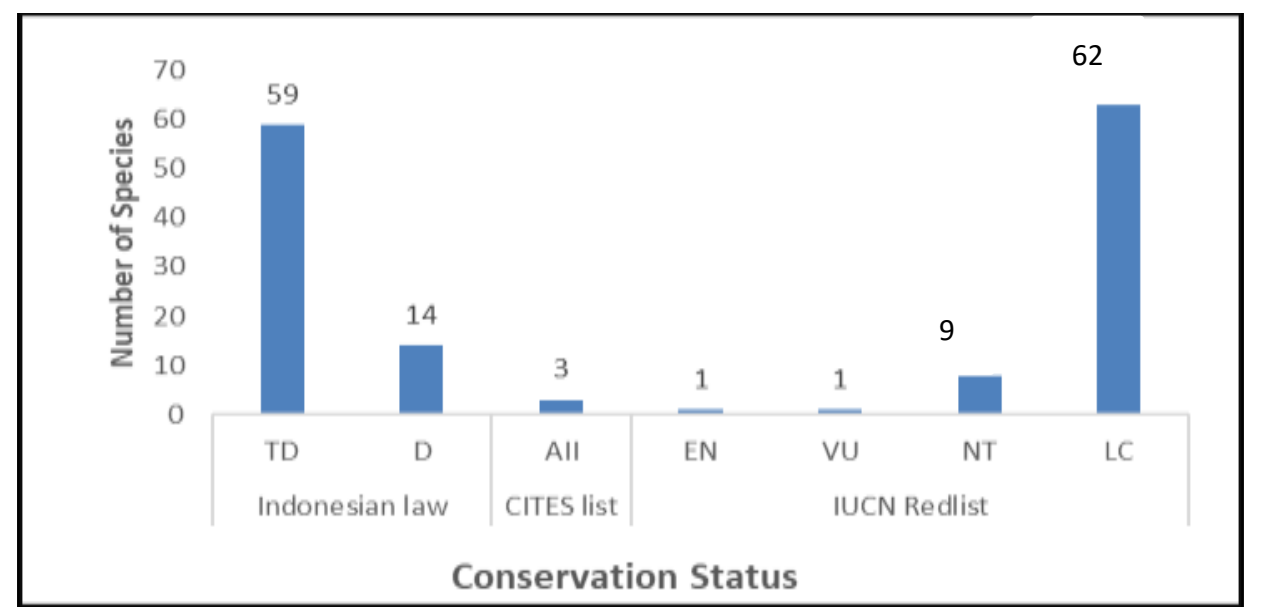

Gambar 3. Status Konservasi Spesis yang Ditemukan di Resort Pemerihan Picture 3. Conservation status of Observed Bird Species in Pemerihan Resort

Ada 14 jenis burung (Lampiran 1) yang dilindungi dalam Permen LHK No. 106 th 2018, sehingga dari status IUCN, CITES dan Permen, keberadaan burung-burung tersebut menjadi perhatian dan prioritas untuk mempertahankannya dari ancaman perburuan, perdagangan dan perusakan habitat. Selain itu, keberadaan jenis-jenis tersebut di Resort Pemerihan TNBBS mengindikasikan bahwa kawasan hutan tersebut merupakan kawasan penting yang perlu dijaga kelestariannya. Tabel 1 menunjukkan famili burung yang ditemukan di Resort Pemerihan.

\section{KESIMPULAN DAN SARAN}

Burung yang dapat ditemukan di Resort Pemerihan TNBBS terdiri 73 jenis dari 32 famili dengan jumlah total individu sebanyak 1.628. Nilai kelimpahan tertinggi yaitu burung layang-layang batu (Hirundo tahitica) sebesar 23,59 \% dan kelimpahan terendah yaitu burung Lanius schach, Lacedo pulchella, Chloropsis cochinchinensis, Nyctyornis amictus, Phaenicophaeus javanicus, Sitta frontalis, Sasia abnormis, Ducula aenea, Eumyias indigo Ceyx erithacus 0, 06\%. Keragaman tertinggi terdapat pada titik 5 dengan $H^{\prime} 3,116$ dengan kategori tinggi $\left(H^{\prime}>3\right)$, sedangkan 5 titik lainnya berada dalam kategori sedang $\left(H^{\prime}<3\right)$. Selain itu, terdapat 14 jenis burung yang dilindungi menurut Permen LHK No 106 tahun 2018 serta 1 burung masingmasing berstatus EN dan VU, 9 burung berstatus NT, dan 3 burung masuk ke dalam kategori All (Appendix II). Hal ini menunjukkan bahwa Resort Pemerihan merupakan area yang penting bagi konservasi burung. Dengan demikian, dapat dilakukan upaya konservasi untuk menjaga kelestarian burung dan pemanfaatannya.

\section{DAFTAR PUSTAKA}

Achsan, A.C., Rizkhi., Awalia, R. (2019). Perencanaan lanskap kawasan perkotaan Kota Palu berbasis mitigasi temperaturpermukaan lahan. Jurnal Belantara, 2(1), 43-52. DOI:https://doi.org/10.29303/jbl.v2i1.97.

Adelina, M., Harianto, S.P., Nurcahyani, N. (2016). Keanekaragaman jenis burung di Hutan Rakyat Pekon Kelungu Kecamatan Kota Agung Kabupaten Tanggamus. Jurnal Sylva Lestari, 4(2),51-60. http://dx.doi.org/10.23960/jsl2451-60. 
Anugrah, K.D., Setiawan, A., Master, J. (2017). Keanekaragaman spesies burung di Hutan Lindung Register 25 Pematang Tanggang Kabupaten Tanggamus Lampung. Jurnal Sylva Lestari, 5(1),105-116. http://dx.doi.org/10.23960/js/1515-116.

Ayat, A. (2011).Burung-Burung Agroforest di Sumatera. Buku. World Agroforestry Centre

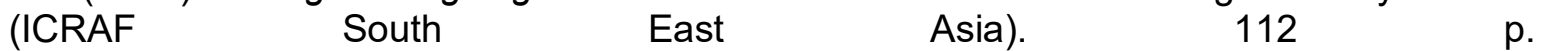
http://apps.worldagroforestry.org/downloads/Publications/PDFS/B17244.pdf

Baskaran, N., Kannan, G., Anbarasan, U.,Thapa, A., Sukumar, R. (2013). A landscape-level assessment of asian elephant habitat, its population and elephant-human conflict in the Anamalai Hill Ranges of Southern Western Ghats, India. Mammalian Biology, 78(6), 470481.

BirdLife International. (2019). Chloropsis cochinchinensis. The IUCN Red List of Threatened Species 2019: e.T103775551A156811213.

Dharmojono. (1996). Aneka Permasalahan Burung dan Ayam Hias Beserta Perpecahannya dalam Pembangunan. Yogyakarta: Liberty.

Erly, H., Wulandari, C., Safe'i, R., Kaskoyo, H., Winarno, G.D. (2019). Keanekaragaman jenis dan simpanan karbon pohon di Resort Pemerihan, Taman Nasional Bukit Barisan Selatan. Jurnal Sylva Lestari, 7(2), 139-149.

Fajar, J. (2020). Burung Layang-Layang Batu, Si Mungil Penolong Petani. Mongabay. https://www.mongabay.co.id/2020/05/24/burung-layang-layang-batu-si-mungil-penolongpetani/amp/. diakses pada 10 Maret 2020. Pukul 17.03 WIB

Firmandi. (2014). Pembuatan Flipbook berdasarkan Keragaman Jenis Burung Diurnal di Hutan Lindung Gunung Senujuh dan Sekitarnya. Skripsi. Program Studi Pendidikan Biologi Jurusan Pendidikan MIPA Pontianak.

Gafur, A., Labiro, E., Ihsan, M. (2016). Asosiasi jenis burung pada Kawasan Hutan Mangove anjungan Kota Palu. Warta Rimba, 4(1),42-48.

Ghifari, B., Hadi, M. dan Tarwodjo, U. (2016). Keanekaragaman dan kelimpahan jenis burung pada Taman Kota Semarang, Jawa Tengah. Jurnal Biologi, 5(4),24-31.

Ichsan, A.C. (2018). Kinerja pembangunan Kesatuan Pengelolaan Hutan Lindung Sungai Wain dan DAS Manggar di Provinsi Kalimantan Timur. Jurnal Belantara, 1(1), 1-9. DOI:10.29303/jbl.v1i1.12.

International Union for Conservation of Nature and Natural Resources. (2020). The IUCN Red List of Threatened Species. Diunduh tanggal 26 September 2020 dari http://www.iucnredlist.org

Issa MAA. (2019). Diversity and abundance of wild birds species in two different habitats at Sharkia Governorate, Egypt. J Basic Appl Zool, 80 (1): 1-7. DOI: 10.1186/s41936-0190103-5

Iswandaru, D., Khalil, A.R.A., Kurniawan, B., Permana, R., Febryano, I.G., Winarno, G.D. (2018). Kelimpahan dan keanekaragaman jenis burung di Hutan Mangrove KPHLGunung Balak. Indonesian Journal of Conservation, 7(1), 57-62.

Iswandaru, D., Novriyanti, Banuwa, I.S., Harianto, S.P. (2020). Distribution of bird communities in University of Lampung, Indonesia. Biodiversitas, 21 (6), 2629-2637.

Iswandaru, D., Febryano, I.G., Santoso, T., Kaskoyo, H., Winarno, G.D., Hilmanto, R., Safe'i, R., Darmawan A., Zulfiani D. (2020). Bird community structure of small islands: a case study on the Pahawang Island, Lampung Province, Indonesia. Silva Balcanica, 21(2), 518.

James, A.O., Emmanuel, D., Bright, A.Y. (2017). Diversity and Abundance of Bird Species in Mole National Park, Damongo, Ghana. Journal of Natural Sciences Research, 7(12) , 20 33.

Jhenkar, M., Jadeyegowda, M., Khusalappa, C.G., Ramesh, M.N., Satish, B.N. (2016). Bird diversity across different vegetation types in Kodagu, Central Westrn Ghats, India. International Journal of Zoology and Research (IJZR), 6(3), 25 - 36. 
Kamal, S., Mahdi, N., Senja, N. (2013). Keanekaragaman jenis burung pada perkebunan kopi di Kecamatan Bener Kelipah, Kabupaten Bener Meriah, Provinsi Aceh. Jurnal Biotik, 1(2), 73 -79 .

Karim, H.A., Nirsyawita, Hamzah, A.S. (2016). Keanekaragaman dan status konservasi spesies avifauna pada Suaka Marga Satwa Mampie, Kabupaten Pole Wali Mandar,Sulawesi Barat. Bioscientiae, 13(1),1-10.

Kiros, S., Afework, B., Legese, K. (2018). A preliminary study on bird diversity and abundance from Wabe fragmented forest around Gubre Subcity and Wolkite Town, Southwestern Ethiopia. -International Journal of Avian \& Wildlife Biology, 3(5), 333-340.

MacKinnon, J., Philipps, K., Balen, B.V. (2010). Seri Panduan Lapangan Burung-Burung di Sumatera, Jawa, Bali, dan Kalimantan. Bogor: LIPI.

Magurran, A.E. (1988). Ecological Diversity and Its Measurement. New Jersey: Princeton University Press.

Miranda, T., Ningsih, S.M., Ihsan, M. (2014). Klasifikasi komunitas burungdi Cagar Alam Gunung Tinombala Kecamatan Mepanga Kabupaten Parigi Moutong. Warta Rimba, 2(2), 33-41.

Meizannur., Wulandari, C. (2015). Analisis pengembangan obyek wisata alam di Resort Balik Bukit Taman Nasional Bukit Barisan Selatan. Jurnal Sylva Lestari, 3(1), 51-62.

Muchlas, M.N., Setiawan, A., Winarno, G.D., Harianto, S.P. (2018). Inventarisasi potensi sumber daya ekowisata di Danau Way Jepara Lampung Timur. Jurnal Belantara, 1(2), 5466. DOI: https://doi.org/10.29303/jbl.v1i2.66

Mukhlisi, Atmoko, T., Rifqi, M.A. (2020). Cica daun, burung kicau yang semakin sepi nyanyinya di alam. Diakses pada 21 Januari 2021 pukul 13.44 WIB. https://www.researchgate.net/profile/Tri Atmoko2/publication/346322698 Cica Daun Bur ung Kicau yang Semakin Sepi Nyanyiannya di Alam/links/5fbe5fb492851c933f58f8acl Cica-Daun-Burung-Kicau-yang-Semakin-Sepi-Nyanyiannya-di-Alam.pdf

Paramita, E.C., Kuntjoro, S., Ambarwati, R. (2015). Keanekaragaman dan kelimpahan jenis burung di Kawasan Mangrove Center Tuban. Jurnal Lentera Bio, 4(3), 161 - 67.

Rajpar MN, Zakaria M. (2011). Bird species abundance and their correlations with microclimate and habitat variables at Natural Wetland Reserve, Peninsular Malaysia. Intl J Zool, DOI: $10.1155 / 2011 / 758573$

Rohiyan. M., Setiawan, A., Rustiati, E.L. (2014).Keanekaragaman spesies burung di Hutan Pinus dan Hutan Campuran Muara Sipongi Kabupaten Mandailing Natal Sumatera Utara. Jurnal Sylva Lestari, 2, 89-98.

Sabaruddin., Yoza, D. Oktorini, Y. (2017). Keanekaragaman jenis burung di Hutan Larangan Adat Kenegerian Rumbio Kecamatan Kampar Kabupaten Kampar Provinsi Riau. JOM FAPERTA UR, 4(2), 1-12.

Sabri, K. (2019). Keanekaragaman Jenis Burung di Hutan Penyangga kawasan Ekosistem Tahura di Kabupaten Pidie sebagai Refereensi Pendukung Materi Ekologi Hewan. Skripsi. Program Studi Pendidikan Biologi. Universitas Islam Negeri Ar-Raniry. Banda Aceh. 122 hlm.

Santosa R.A., Harianto S.P. dan Nircahyani N. (2016). Perbandingan populasi burung cekakak (halcyonidae) di Lahan Basah Desa Sungai Luar dan Lahan Basah Desa Kibang Pacing. Jurnal Sylva Lestari, 4(2),79-88.

Schmidt, F. H. dan Ferguson, J. H. A. (1951).Rainfall Types Based On Wet and DryPeriod Rations for Indonesia With Western New Guinea. Jakarta: Kementrian Perhubungan Meteorologi dan Geofisika.

Simanjutak, E. J., Nurdjali, B., Siahaan, S. (2013). Keanekaragaman jenis burung diurnal di Perkebunan Kelapa Sawit PTPN XIII Desa Amboyo Inti Kecamatan Ngabang Kabupaten Landak. Jurnal Hutan Lestari,1(13),317-326. 
Sukmantoro, W., Irham, M., Novarino, W., Hasudungan, F., Kemp, N., Muchtar, M. (2007). Daftar Burung Indonesia no. 2. Bogor:Indonesia Ornitologists Union.

Sulistyadi, E. (2010). Kemampuan kawasan nir konservasi dalam melindungi kelestarian burung endemik dataran rendah Pulau Jawa Studi Kasus di Kabupaten Kebumen. Jurnal Biologi Indonesia, 6(2), 237 - 253.

Taufan, M. (2008). Keanekaragaman Jenis Burung (Aves) Di Tahura Desa Pombewe Kecamatan Sigi Biromaru Kabupaten Donggala. Fakultas Kehutanan Universitas Tadulako. Palu.

Tesfahunegny, W., Fekensa, T., Mulualem, G. (2016). Avifauna diversity in Kafa Biosphere Reserve: Knowledge and perception of villagers in Southwest Ethiopia. - Ecology and Evolutionary Biology, 1(2), 7-13.

The Convention on International Trade in Endangered Species of Wild Fauna and Flora. (2020). Checklis of CITES. Diunduh tanggal 06 November 2020 dari http://www.checklist.cites.org

Wahyuni, P., Febriyano, I.G., Iswandaru, D., Dewi, B.S. (2020). Sebaran lutung Trachypithecus cristatus (Raffles, 1821) di Pulau Pahawang, Indonesia. Jurnal Belantara, 3(2),89-96. DOI:https://doi.org/10.29303/jbl.v3i2.473.

Wardani, M., Heriyanto, N. M., and Heriyanto, N. M. (2016). Autekologi damar asam shorea hopeifolia (F. Heim) Symington di Taman Nasional Bukit Barisan Selatan, Lampung. Buletin Plasma Nutfah, 21(2), 89-98. DOI: 10.21082/blpn.v21n2.2015.p89-98

Widodo, W. (2009). Komparasi keragaman jenis burung-burung di Taman Nasional Baluran dan Alas Purwo pada beberapa tipe habitat. Jurnal Berkala Penelitian Hayat, (14),113-124.

Wulandari, S., Ichsan, A.C., Syahputra, M. (2019). Perilaku sosial jalak bali (Leucopsar rothschildi stresemann 1912) di kandang perkembangbiakan unit pengelolaan khusus pembinaan jalak bali Tegal Bunder Taman Nasional Bali Barat. Jurnal Belantara, 2(1), 1016. DOI:https://doi.org/10.29303/jbl.v2i1.70. 
Lampiran 1. Kelimpahan jenis burung di Resort Pemerihan TNBBS Attachment 1. Abundance birds species of Pemerihan Resort in TNBBS

\begin{tabular}{|c|c|c|c|c|c|c|c|c|}
\hline No & Nama & Nama IImiah & Famili & Jumlah & KR (\%) & Permen LHK No. 106 th 2018 & IUCN & CITES \\
\hline 1 & Alap-alap capung & Microhierax fringillarius & Falconidae & 34 & 2,13 & Dilindungi & $\mathrm{LC}$ & All \\
\hline 2 & Apung tanah & Anthus novaeseelandiae & Motacillidae & 2 & 0,13 & Tidak Dilindungi & LC & - \\
\hline 3 & Ayam-hutan merah & Gallus gallus & Phasianidae & 5 & 0,31 & Tidak Dilindungi & LC & - \\
\hline 4 & Bentet Kelabu & Lanius schach & Laniidae & 1 & 0,06 & Tidak Dilindungi & LC & - \\
\hline 5 & Bondol jawa & Lonchura leucogastroides & Estrildidae & 72 & 4,51 & Tidak Dilindungi & LC & - \\
\hline 6 & Bondol peking & Lonchura punctulata & Estrildidae & 78 & 4,88 & Tidak Dilindungi & LC & - \\
\hline 7 & Bubut alang-alang & Centropus bengalensis & Cuculidae & 3 & 0,19 & Tidak Dilindungi & LC & - \\
\hline 8 & Burung Madu sriganti & Nectarinia jugularis & Nectariniidae & 2 & 0,13 & Tidak Dilindungi & LC & - \\
\hline 9 & Burung-madu polos & Anthreptes simplex & Nectariniidae & 12 & 0,75 & Tidak Dilindungi & LC & - \\
\hline 10 & Cabai bunga api & Dicaeum trigonostigma & Dicaeidae & 7 & 0,44 & Tidak Dilindungi & LC & - \\
\hline 11 & Cabai merah & Dicaeum cruentatum & Dicaeidae & 2 & 0,13 & Tidak Dilindungi & LC & - \\
\hline 12 & Cabai rimba & Dicaeum chrysorrheum & Dicaeidae & 14 & 0,88 & Tidak Dilindungi & LC & - \\
\hline 13 & Cekakak batu & Lacedo pulchella & Alcedinidae & 1 & 0,06 & Tidak Dilindungi & LC & - \\
\hline 14 & Cekakak belukar & Halcyon smyrnensis & Alcedinidae & 9 & 0,56 & Tidak Dilindungi & LC & - \\
\hline 15 & Cekakak sungai & Todiramphus chloris & Alcedinidae & 22 & 1,38 & Tidak Dilindungi & LC & - \\
\hline 16 & Cica-daun kecil & Chloropsis cyanopogon & Chloropseidae & 10 & 0,63 & Dilindungi & NT & - \\
\hline 17 & Cica-daun sayap-biru & Chloropsis cochinchinensis & Chloropseidae & 1 & 0,06 & Dilindungi & EN & - \\
\hline 18 & Cinenen kelabu & Orthotomus ruficeps & Sylviidae & 25 & 1,56 & Tidak Dilindungi & LC & - \\
\hline 19 & Cipoh jantung & Aegithina viridissima & Aegithinidae & 16 & 1 & Tidak Dilindungi & NT & - \\
\hline 20 & Cirik-cirik kumbang & Nyctyornis amictus & Meropidae & 1 & 0,06 & Tidak Dilindungi & LC & - \\
\hline 21 & Ciung-air coreng & Macronous gularis & Timaliidae & 30 & 1,88 & Tidak Dilindungi & LC & - \\
\hline 22 & Cucak kuning & Rubigula dispar & Pycnonotidae & 70 & 4,38 & Tidak Dilindungi & LC & - \\
\hline 23 & Elang brontok & Nisaetus cirrhatus & Accipitridae & 4 & 0,25 & Dilindungi & LC & - \\
\hline 24 & Elang hitam & Ictinaetus malayensis & Accipitridae & 10 & 0,63 & Dilindungi & LC & - \\
\hline 25 & Elang-ular bido & Spilornis cheela & Accipitridae & 8 & 0,5 & Dilindungi & LC & All \\
\hline 26 & Enggang klihingan & Anorrhinus galeritus & Bucerotidae & 10 & 0,63 & Dilindungi & NT & - \\
\hline 27 & Gagak kampung & Corvus macrorhynchos & Corvidae & 10 & 0,63 & Tidak Dilindungi & LC & - \\
\hline 28 & Jingjing batu & Hemipus hirundinaceus & Campephagidae & 3 & 0,19 & Tidak Dilindungi & LC & - \\
\hline 29 & Jingjing petulak & Tephrodornis gularis & Campephagidae & 2 & 0,13 & Tidak Dilindungi & LC & - \\
\hline 30 & Kadalan Beruang & Phaenicophaeus diardi & Cuculidae & 2 & 0,13 & Tidak Dilindungi & NT & - \\
\hline 31 & Kadalan Birah & Phaenicophaeus curvirostris & Cuculidae & 6 & 0,38 & Tidak Dilindungi & LC & - \\
\hline 32 & Kadalan kembang & Phaenicophaeus javanicus & Cuculidae & 1 & 0,06 & Tidak Dilindungi & LC & - \\
\hline 33 & Kadalan selaya & Phaenicophaeus chlorophaeus & Cuculidae & 31 & 1,94 & Tidak Dilindungi & LC & - \\
\hline 34 & Kirik-kirik senja & Merops leschenaulti & Meropidae & 55 & 3,44 & Tidak Dilindungi & LC & - \\
\hline 35 & Kuau Raja & Argusianus argus & Phasianidae & 10 & 0,63 & Dilindungi & NT & - \\
\hline 36 & Kucica kampung & Capsychus saularis & Turdidae & 2 & 0,13 & Tidak Dilindungi & LC & - \\
\hline 37 & Kutilang & Pycnonotus aurigaster & Pycnonotidae & 146 & 9,14 & Tidak Dilindungi & LC & - \\
\hline 38 & Layang-layang batu & Hirundo tahitica & Dicaeidae & 377 & 23,59 & Tidak Dilindungi & LC & - \\
\hline 39 & Merbah belukar & Pycnonotus plumosus & Pycnonotidae & 43 & 2,69 & Tidak Dilindungi & LC & - \\
\hline 40 & Merbah cerukcuk & Pycnonotus goiavier & Pycnonotidae & 106 & 6,63 & Tidak Dilindungi & LC & - \\
\hline
\end{tabular}


Jurnal Belantara Vol. 5, No 1, Maret 2022 (131-142)

41 Merbah corok-corok 42 Merbah kacamata

\begin{tabular}{ll}
\hline 43 & Merbah mata merah \\
44 & Munguk beledu \\
45 & Paok pancawarna-sumatera \\
46 & Pelatuk kundang \\
47 & Pelatuk sayap merah \\
48 & Pentis pelangi \\
49 & Perenjak gunung \\
50 & Pergam hijau \\
51 & Perkutut jawa \\
52 & Perling kumbang \\
53 & Punai gading \\
54 & Punai kecil \\
55 & Raja-udang biru \\
56 & Raja-udang meninting \\
57 & Rangkong Badak \\
58 & Sempur-hujan darat \\
59 & Sempur-hujan sungai \\
60 & Sikatan bubik \\
61 & Sikatan ninon \\
62 & Srigunting batu \\
63 & Takur ampis-sumatera \\
64 & Takur ungkut-ungkut \\
65 & Takur warna warni \\
66 & Tangkar Kambing \\
67 & Tekukur biasa \\
68 & Tiong emas \\
69 & Tukik tikus \\
70 & Udang api \\
71 & Uncal Kouran \\
72 & Walet sapi \\
73 & Wiwik kelabu \\
\hline
\end{tabular}

Pycnonotus simplex

Pycnonotus erythropthalmos

Pycnonotus brunneus

Sitta frontalis

Hydrornis irena

Chrysocolaptes validus

Picus puniceus

Prionochilus percussus

Prinia superciliaris

Ducula aenea

Geopelia striata

Aplonis panayensis

Treron vernans

Treron olax

Alcedo coerulescens

Alcedo meninting

Buceros rhinoceros

Eurylaimus ochromalus

Cymbirhynchus macrorhynchos

Muscicapa dauurica

Eumyias indigo

Dicrurus paradiseus

Caloramphus hayii

Psilopogon haemacephalus

Megalaima mystacophanos

Platysmurus leucopterus

Spilopelia chinensis

Gracula religiosa

Sasia abnormis

Ceyx erithacus

Macropygia emiliana

Collocalia esculenta

Cacomantis merulinus
LC -

LC -

Pycnonotidae

22

1,38

ilindungi

Tidak Dilindungi

Tidak Dilindungi

Tidak Dilindur

Tidak Dilindung

Tidak Dilindung

Tidak Dilindung

Tidak Dilindung

Tidak Dilindungi

Tidak Dilindungi

Tidak Dilindungi

Tidak Dilindungi

Tidak Dilindung

Tidak Dilindung

Tidak Dilindung

Tidak Dilindung

Dilindungi

Tidak Dilindungi

Tidak Dilindungi

Tidak Dilindungi

Tidak Dilindung

Tidak Dilindungi

Dilindungi

Tidak Dilindungi

Dilindungi

Dilindungi

Tidak Dilindungi

Dilindungi

Tidak Dilindung

Tidak Dilindung

Tidak Dilindung

Tidak Dilindung

Tidak Dilindung

\section{Picidae}

Columbidae

Apodidae

NT -

LC -

Cuculidae

1628 